\title{
MARINE SPATIAL PLANNING AND THE LOCAL COMMUNITY'S AWARENESS OF ECOSYSTEMS IN SETIU WETLAND
}

Lua Wei Yien, ${ }^{1 *}$ Nazli Aziz, ${ }^{1,2 * *}$ Farahdilah Ghazali, ${ }^{4}$ Izwandy Idris, ${ }^{3}$ Nor Hafzan Abd Rasid, 1 \& Wan Izatul Asma Wan Talat ${ }^{1}$

*First author, ${ }^{* *}$ corresponding author

${ }^{1}$ Centre for Ocean Governance, Institute of Oceanography and Environment, Universiti Malaysia Terengganu, Malaysia

${ }^{2}$ Faculty of Business, Economics and Social Development, Universiti Malaysia Terengganu, Malaysia

${ }^{3}$ South China Sea Repository and Reference Centre, Institute of Oceanography and Environment, Universiti Malaysia Terengganu, Malaysia

${ }^{4}$ Faculty of Fisheries and Food Science, Universiti Malaysia Terengganu, Malaysia (wylua950305@gmail.com,* nazli_aziz@umt.edu.my, ** farahdilah.g@umt.edu.my, izwandy.idris@umt.edu.my, norhafzanrasid@gmail.com, wia@umt.edu.my) DOI: https://doi.org/10.22452/jati.vol26no1.5

\section{Abstract}

Many wetlands have experienced rapid degradation that is due to unstainable development practices globally. Oftentimes, uncoordinated economic development plans in wetlands and surrounding areas have affected the ecological functions of these sensitive ecosystems. This study examined Setiu Wetland, a wetland with diverse ecosystems on the east coast of Peninsular Malaysia. The main objective of this study was to analyse the potential of marine spatial planning (MSP) to be adopted there. MSP is an integrated coastal zone management tool to govern conflicting uses of an area considering environmental sustainably. Like other coastal zone managements adopted in Southeast Asia, MSP requires participation and awareness of the local community to ensure sustainable development targets are achieved. This paper addresses the local community's awareness of the ecosystem importance of Setiu Wetland and the socio-economic activities in the area. The study employed a quantitative approach using a survey method to examine, in particular, the local community's awareness of the oyster habitat that has a direct impact on the Setiu Wetland ecosystems. The research findings indicate that awareness of the importance of oyster habitats to the wetland ecosystems is high among the local community. The community strongly supports the idea of protecting and preserving the wetland to ensure the healthy functioning of ecosystems.

Keywords: marine spatial planning, Setiu Wetland, awareness, local community, ecosystems 


\section{Introduction}

Wetlands worldwide are facing degradation at an accelerated rate owing to reclamation and pollution along with socio-economic developments, including that of Setiu Wetland. No specific legislation relating to the conservation and management of wetlands is available in Malaysia. International conventions, such as the Ramsar Convention, and international declarations, such as the Langkawi Declaration and the Rio Declaration, govern their management (Ibrahim, Aziz, \& Hanifah, 2012a). The Ramsar Convention initially focused on the significance of waterfowl habitats, but after many years extended its scope to include all aspects of wetland management and the conscientious use of all wetlands.

The Langkawi Declaration on the Environment 1989 aims to balance the protection of the environment while promoting economic growth and sustainable development. This declaration was an initiative of the Commonwealth Government heads of government to warn about the severity of deterioration in the environment and the adverse impacts on the wellbeing of present and future generations. In 1989, Malaysia also made a "Pledge for the Environment", using the concept of sustainable development to preserve and enhance Malaysia's environment quality in line with the Langkawi Declaration (Wan Mohd., 2013).

Three years later, the Rio Declaration on Environment and Development was formulated at the United Nations Conference on Environment and Development (UNCED) in Rio de Janeiro in 1992. This declaration is of great significance because of its recognition of the principles acknowledging the importance of preserving the environment and has also produced international guidelines to achieve its objectives. The declaration further recognised the important role of indigenous and local communities, as demonstrated in Principle 22:

Indigenous people and their communities and other local communities have a vital role in environmental management and development because of their knowledge and traditional practices. States should recognise and duly support their identity, culture and interests and enable their effective participation in the achievement of sustainable development.

Alexandre Kiss, the President of the European Council for Environmental Law, made a significant remark on this Convention:

The Rio Conference ... is like a bottle which is seen half full or half empty. The Declaration itself has disappointed some, who hold that it does not constitute real progress when compared to the Stockholm Declaration and the 1982 World Charter for Nature ... (Viñuales, 2015). 
Malaysia should therefore adopt a constructive policy as a state party to the convention to encourage the protection and conservation of wetlands, which are critical ecosystems that should be conserved from environmental, social and economic perspectives. Several significant national laws are in place for wetland management, including the Forestry Act 1984, the National Parks Act of 1980, the Wildlife Conservation Act 2010, the International Trade in Endangered Species Act 2008 and the Environmental Quality Act 1974.

Wetlands have improved water quality for human consumption as well as improving ecosystem and species biodiversity, which has created sustainable habitats for wildlife, from low trophic to higher trophic species (Shaharuddin et al., 2014). Wetlands also play a critical role in mitigating climate change and safeguarding communities from the impact of a changing climate system (Moomaw et al., 2018). Unfortunately, just like other wetlands, Setiu Wetland is under great pressure from surrounding developments that have negatively affected its ecosystems. Bivalve species, including oysters, are among the organisms heavily affected since they are sessile. Owing to their feeding mechanism, bivalves filter suspended particles in water (Azlisham, Vedamanikam, \& Shazilli, 2009), which includes pollutant particles found in the water, such as arsenic, mercury (Affizah, Vedamanikam, \& Shazilli, 2009), zinc and copper (Najiah et al., 2008). Alas, the ecological importance of bivalves, particularly oysters, is not widely known among the local communities consuming them (Yahya et al., 2016). Many studies conducted have focused on the importance of wetland management and mangrove conservation in wetlands. However, there appears to be a disconnect between the importance of conserving oyster ecosystems and the sustainability of wetland management. This could be attributed to the fact that very few studies have been conducted on the ecological function of oysters.

It has also been proven that to achieve the Sustainable Developments Goals targeted under the United Nations Global Agenda 2030, participation of local stakeholders must be considered. This could be realised through marine spatial planning (MSP), which is a sustainable management tool used by many countries to manage their coastal areas effectively. Sustainable management is crucial to conserving the environment and ensuring ongoing socio-economic developments (Aziz, Muhammad, Farahdilah, Talaat, \& Saputra, 2019). However, MSP in Malaysia is still a new concept. Therefore, this study aimed to examine the ecosystems of Setiu Wetland and the socio-economic activities surrounding the oysters' ecosystems in light of the possibility of implementing MSP to reduce conflicting uses of the wetland in the future. 


\section{Literature Review}

To understand the connection between ecosystems and planning mechanisms, the literature review had two main focuses: wetland ecosystems and MSP. Regarding wetland ecosystems, the discussion extends to Setiu Wetland and the oyster ecosystem. Integrated management of the spatial and temporal distribution of the coastal areas activities is discussed in relation to MSP as the planning tool and framework for this study. It is important to emphasise MSP in the literature review to gain a deeper understanding of how a planning tool can be implemented to improve the management and governance of a wetland in Malaysia.

\section{Wetland Ecosystems}

Ecosystems must be managed and governed carefully because of the services provided by the ecosystem to our wellbeing. Sustainable ecosystems provide services directly and indirectly to the world population, such as safe food, clean air and water, and green areas (Dyke \& Lamb, 2020). Tsujimoto, Kajikawa, Tomito, and Matsumoto (2018) define an ecosystem as a biological system composed of all organisms found in a physical environment, interacting with the environment and among each other. It is the basis of nature and comprises two interacting components, those being non-living physical elements and living organisms. Nonliving physical elements refers to the climate, temperature and $\mathrm{pH}$ levels of an ecosystem, while, living organisms refers to the animals, plants and bacteria within the ecosystem. Ecosystems may also be described as a group of interacting organisms that depend on and are influenced by activities carried out by each other (Jacobides, Cennamo, \& Gawer, 2018). Meanwhile, Zhao and Costello (2019) defined an ecosystem as an enduring, spatially bounded environment where biological and energy interactions are greater within that environment than with other ecosystems.

Around $70 \%$ of the earth is covered by marine ecosystems, which provide many monetary and non-monetary benefits (Selig et al., 2019). Wetlands represent one of these ecosystems. According to Haron, Aziz, Ghani, and Amirah (2020), wetlands are often undervalued and not prioritised in coastal management decisions, although they are rich in biodiversity, thereby providing habitats for a huge number of organisms, including endangered species. Wetlands are important to society and economy, yet their ecosystems are particularly vulnerable to climate change. Many scientists and policymakers are ignorant of the significant role of wetlands' carbon storage in the management and policy of wetlands (Moomaw et al., 2018). In particular, Setiu Wetland is a unique wetland that has nine interconnected ecosystems (Yahya et al., 2016). It is home to the critically endangered painted terrapin and river terrapin (Mohd. Salim, Mohamad., \& 
Shahrudin, 2015), and provides a habitat for economically important mud crab species as well as 29 mammals species, 161 birds species, and 36 reptile and amphibians species (Ikhwanuddin, Azmi, Borkhanuddin, Muhammad, \& Idris, 2017; World Wildlife Fund [WWF], 2013).

However, natural wetlands all around the world are suffering from degradation at a speedy rate (Bai, Cui, Cao, Li, \& Zhang, 2013; Davidson, FluetChouinard, \& Finlayson, 2018) because of reclamation, pollution and change in land use to satisfy development needs. For socio-economic developments to be conducted without harming the environment, wetland resources must be carefully managed to ensure their long-term sustainability (Aziz et al., 2019); these wetland areas ought to be protected and managed properly. It is in fact our duty to understand the dynamics affecting these ecosystems and safeguard their protection. Moreover, laws will only be adequate if accompanied by effective enforcement of wetland conservation (Ibrahim et al., 2012a).

In a study conducted by Ibrahim, Aminudin, Young, and Yahya (2012b), semistructured interviews with local people were used to examine their perceptions of the importance of wetland management. It was believed effective management of these resources was inspired by public understanding of the value of wetlands. Environmental education fosters behavioural change, which helps protect habitat and preserve wetlands (Ibrahim et al., 2012b). Meanwhile, a study by Hassan et al. (2016) examined the attitudes of urban and rural people towards the protection of Setiu Wetlands. The findings showed most respondents, who were urban citizens, had optimistic attitudes towards all facets of wetland protection.

Areas of wetlands, mangroves particularly, are often disregarded as unproductive areas (Brander et al., 2012). Setiu Wetland is one of the most undervalued wetlands with the potential to deteriorate in the region (Hassan et al., 2016). Thus, as our wetlands are rich and are known as habitats for many species and contribute to the ecosystem's hydrological, biological and ecological functions (Ibrahim et al., 2012a), it is crucial to adopt a sustainable development principle in the Setiu Wetland development policy. A publication released by the World Commission on Environment and Development in 1987, known as the Brundtland Report or Our Common Future, introduced the concept of sustainable development. The Brundtland Report defined sustainable development as a balanced development able to cater to present societal needs without jeopardising the needs of future generations to survive (Jarvie, 2016). Moreover, the report mentioned the importance of involving local communities, or so-called grass-roots communities, in the decision-making process to achieve sustainable resources management. Padfield et al. (2015) have highlighted the sustainable management of wetlands as an approach to achieving sustainable development as promoted in the 
international agenda. Wetlands are vital for regional sustainable development owing to their ability to increase the wetlands' and community's resilience to extreme weather; they ensure coastal sustainability and thereby address the needs of both the health of coastal wetlands and the resilience of urban economics (Chuang, Yu, Chen, Chen, \& Su, 2018).

The term 'sustainable development' has become a popular catchphrase in academia, policymaking, development planning and environmental NGOs when discussing, proposing and making decisions regarding current and future development globally. Generally, all sustainable development theories, concepts or frameworks entail a development idea that prevents degradation and pollution to protect and restore our surrounding ecosystems and habitats. Sustainable development does not sideline the issue of global poverty but reinforces a winwin situation between human beings and environmental protection for the needs of today and the future (Mensah, 2019; Molinoari et al., 2019; Cruickshank, Schneeberger, \& Smith, 2012; Dernbach, 2003). Mensah (2019) proposed that to achieve a sustainable development status, a time framework to achieve it can be established specifically or indefinitely. Several main principles must be undertaken to achieve sustainable development. It is also argued (Mensah, 2019; Molinoari et al., 2019) that ecosystem conservation is the main principle because no living organism will thrive without a healthy ecosystem and biodiversity. Therefore, any development must consider the earth's capacity to adapt to the changes. Moreover, population control, resources management and community participation are also factors that would determine success in sustainable development (Mensah, 2019; Molinoari et al., 2019).

Globally, the concern of sustainability has been translated through the Sustainable Development Goals, which were adopted by all United Nations member states at the United Nations Sustainable Development Summit in September 2015. The goals are also known as the 2030 Agenda for Sustainable Development or the United Nations 2030 Agenda. With reference to the 17 goals, the ecosystems of wetlands are closely related to the marine environment under 'Goal 14: Life below Water' and 'Goal 15: Life on Land'. For example, Goal 14 encourages people to buy only those ocean products that are needed, use less single-use plastic and organise beach clean-ups. Meanwhile, Goal 15 encourages people to recycle more, involve local communities in development and management, and promote reforestation.

Many studies have demonstrated success in sustainable coastal management that is due to the participatory approach of local stakeholders in the governance framework; therefore, many countries had switched from a top-down to a bottom-up approach. Local communities usually initiate this bottom-up 
approach regarding local coastal issues and address real issues that are often easy to solve because they respond to a localised problem (Hagan \& Ballinger, 2010). Meanwhile, a top-down approach is defined as a setback for integrated coastal management because it does not consider local conditions adequately (Portman, Esteves, Le, \& Khan, 2012). The table below provides studies that have reported achievements in sustainable coastal management that included the local society in the decision-making process.

Table 1: Studies finding local engagement in governance systems helps achieve the success of sustainable ocean and coastal management

\begin{tabular}{|c|c|}
\hline ournal & of Findings \\
\hline $\begin{array}{l}\text { Community-based } \\
\text { Marine Resource } \\
\text { Management in the } \\
\text { South Pacific }\end{array}$ & $\begin{array}{l}177 \text { villages in Fiji province have community-based } \\
\text { management measure; } 80 \text { villages in Vanuatu actively } \\
\text { manage marine resources locally. Community-based } \\
\text { resources management is a promising approach for coastal } \\
\text { areas in Pacific Island communities (Govan, Tawake, \& } \\
\text { Tabunakawai, 2006). }\end{array}$ \\
\hline $\begin{array}{|lr|}\text { Integrated } & \text { Coastal } \\
\text { Zone Management in } \\
\text { Vietnam (ICZM): } \\
\text { Pattern r and } \\
\text { Perspectives }\end{array}$ & $\begin{array}{l}\text { Visible Integrated Coastal Zone Management (ICZM) results } \\
\text { depend on action at the district level, and local authority } \\
\text { involvement is important for effective coastal management } \\
\text { (An. Phung, \& Chau, 2008). }\end{array}$ \\
\hline $\begin{array}{l}\text { Community-Based } \\
\text { Coastal Zone } \\
\text { Management in } \\
\text { Bangladesh }\end{array}$ & $\begin{array}{l}\text { munities in Bang } \\
\text { nt to reduce the ris } \\
\text { With mitigation } \mathrm{m} \\
\text { el, they succeeded } \\
\text { cyclones (Parvin, }\end{array}$ \\
\hline $\begin{array}{l}\text { Participatory } \\
\text { Integrated Coastal } \\
\text { Zone Management in } \\
\text { Vietnam: Theory } \\
\text { Versus Practice Case } \\
\text { Study: Thua Thien } \\
\text { Hue Province }\end{array}$ & $\begin{array}{l}\text { Local stakeholders applied participatory management and } \\
\text { showed positive achievements. To ensure the longevity of } \\
\text { Integrated Coastal Zone Management (ICZM), knowledge } \\
\text { sharing is crucial and the top-down tradition approach is a } \\
\text { challenge to achieve sustainable management (Abelshausen, } \\
\text { Vanwing, \& Jacquet, 2015). }\end{array}$ \\
\hline $\begin{array}{l}\text { Integrated Coastal } \\
\text { Management (ICM) } \\
\text { Implementation and } \\
\text { Scaling Up in } \\
\text { Chonburi Province, } \\
\text { Thailand }\end{array}$ & $\begin{array}{l}\text { A visible improvement can be seen, such as clean beaches } \\
\text { and a rise in public environmental awareness in the } \\
\text { Integrated Coastal Management (ICM) initiation, which } \\
\text { involves local communities and local and national } \\
\text { governments in Chonburi, Thailand (Barnette \& Wiwekwin, } \\
\text { 2018). }\end{array}$ \\
\hline
\end{tabular}




\begin{tabular}{|c|c|}
\hline $\begin{array}{l}\text { Integrated } \\
\text { Community-Based } \\
\text { Coastal Management: } \\
\text { Lesson from The Field }\end{array}$ & $\begin{array}{l}\text { With funding from government and involvement from local } \\
\text { people, people in Mangunharjo successfully coped with } \\
\text { coastal erosion, and local people benefited in terms of coastal } \\
\text { protection and socio-economic conditions (Hadi, 2018). }\end{array}$ \\
\hline $\begin{array}{lr}\text { Keeping } & \text { the } \\
\text { Essentials } & \text { Flowing: } \\
\text { Promoting } & \text { Food } \\
\text { Security } & \text { and } \\
\text { Sustainable } & \\
\text { Livelihood } & \text { through } \\
\text { Integrated } & \text { Coastal } \\
\text { Management } & \end{array}$ & $\begin{array}{l}\text { The local people in Batangas gained funding for fuel for their } \\
\text { boats from the local government and carried out patrolling } \\
\text { voluntarily by using their own boats. They successfully } \\
\text { reduced illegal fishing and increased environmental } \\
\text { awareness among local people (World Bank, 2009). }\end{array}$ \\
\hline
\end{tabular}

Sources: Abelshausen et al. (2015); An et al. (2008); Barnette, and Wiwekwin (2018); Govan et al. (2006); Hadi (2018); Parvin et al. (2010); World Bank (2009).

Several studies have also identified that failure to maintain sustainable management efforts has been due to the exclusion of local stakeholders. Beeharry, Makoondlall-Chadee, and Bokhoree (2014) stated that when an integrated coastal zone management (ICZM) initiative in Mauritius did not include the local stakeholders in its management, this had a negative impact on the management. Further, a collapse of integrated management in Cuba was also due to lack of public participation in local initiatives (Gerhartz-Abraham, Fanning, \& AnguloValdes, 2016).

The concept of ICZM was first defined in 1992 by the UNCED. It is a process of taking a balanced approach between socio-economic and environmental sustainability. Douvere (2008) stated that ICZM is an ecosystembased approach that focuses on integrated management across sectors and takes into account ecological considerations.

\section{Setiu Wetland, Terengganu}

Located in the Setiu District, Setiu Wetland is the largest natural wetland on the east coast of Peninsular Malaysia (Ikhwanuddin et al., 2017) and the second largest mangrove forest in Terengganu (Saleh \& Muslim, 2017). The wetland is influenced by four rivers, namely, Sungai Setiu, Sungai Chalok, Sungai Bari and Sungai Merang. The 26-kilometres-long lagoon is only 1.5 kilometres at the widest section and is separated from the South China Sea by a narrow stretch of barrier islands (Haron et al., 2020). This wetland is exposed to north-east monsoons from November to March and south-east monsoons from May to September, and the temperature ranges from $28{ }^{\circ} \mathrm{C}$ to $33{ }^{\circ} \mathrm{C}$ (Suratman et al., 2016). The human populations in Setiu District consist of mainly ethnic Malay, followed by small 
numbers of Chinese, Indians and others. According to the Setiu Wetland Special Area Plan (SWSAP), which was published by PLANMalaysia in 2019, the wetland covers 57,376.89 hectares in total with 16,052 households in 2016.

In addition, this wetland is home to various species including fish, invertebrates, reptiles, birds and coastal vegetation. Setiu Wetland also serves as a habitat for endangered species. Therefore, many conservation programmes have been implemented from 1995 to today to protect the ecosystem functions. Setiu Wetland was designated as the first state park in Terengganu, which was gazetted on 10 May 2018 (Yayasan Diraja Sultan Mizan, 2018).

Being a diverse ecosystem, the nine interdependent ecosystems offer rich biological diversity, which creates numerous economic opportunities, especially for nearby communities. Some of the activities surrounding the wetland include aquaculture, boating, palm oil plantations, silica mining and artisanal fisheries. These rapidly growing developments have been responsible for many negative impacts on the wetland and organisms within.

Reclamation has reduced swamp coverage areas and led to sedimentation, which has increased the total suspended solids in the water body (Mohd. Salim et al., 2015). Clearance of mangrove areas for developments promotes destabilisation of coastal areas because mangrove forests help reduce wave action. The concentration of ammonia has also increased in areas near aquaculture farms owing to excessive fish food usage and waste products (Bakar, Jusoh, Ahmad, Noor, \& Norzilah, 2016). Discharge of effluent from shrimp ponds into Sungai Chalok, which eventually flows into Setiu Wetland, is another threat to the wetland (World Wildlife Fund [WWF], 2013). Moreover, the nitrates, phosphate and ammonia concentration from agricultural activities nearby would increase the nutrient levels in the wetland (Poh, Ng, Suratman, Mathew, \& Tahir, 2019). Oil spills from boating activities that take place every day in the wetland for many purposes are unavoidable and have long-term negative implications for the environments (Ghazali \& Hamzah, 2014).

\section{Oyster Ecosystems}

Many types of ecosystems exist, such as grassland, tundra, forest, freshwater, coral reef, wetland, estuary and savanna. In a wetland, the ecosystems are closely interrelated with marine and aquatic species. In general, oyster ecosystems play important roles in maintaining the ecological balance of the wetlands. Similar ecological roles are played by oysters in Malaysian waters, including in the Setiu Wetland, where oysters can be found naturally.

Generally, as a filter feeder, oysters feed on suspended particles and help reduce turbidity. According to Akdeniz (2017), an oyster can filter about four to 20 
litres of seawater in an hour. Because of the feeding mechanism, oysters accumulate particles found inside water columns and serve as good bio-indicators (Azlisham et al., 2009); therefore, they are sensitive to pollution such as arsenic, mercury, zinc and copper (Affizah et al., 2009; Najiah et al., 2008). This type of filter feeder also contributes to nutrient recycling in the ecosystem (Panawala, 2017). Additionally, water quality improvement in terms of decreased turbidity, increased light penetration, and seston and phytoplankton depletion also result from filtration by oyster populations (French McCay, Peterson, DeAlteris, \& Catena, 2003; Newell \& Koch, 2004; Coen et al., 2007).

Oyster reefs are home to various species of polychaete, fish larvae and epifauna (Rodney \& Paynter, 2006), which help stabilise the shoreline and sediment (Zedler, 2004) by reducing wave energy and slowing down erosion (Coen et al., 2007). Moreover, living and recently dead oysters can attract spatfall and promote the setting of mature larvae (Lillis, Eggleston, \& Bohnenstiehl, 2013). The spatfall would delay settlement increases the mortality rate and hence reduces recruitment.

Oysters are an important commercial species of bivalve. Teh, Zulfigar, and Tan (2012) reported that they are one of the most famous shellfish and commonly consumed by Malaysians. Oysters are sold for RM16.50-RM24 per kg without shell and RM28 per kg with shell (price on Shoppe in 2021) or RM40/kg without shell and RM15-RM33 with shell (price on Facebook in 2021). They are also sold as a fresh live oysters in hotels and restaurants (Tan et al., 2014). Moreover, discarded oyster shells can create art and souvenirs sold for tourists (Liang \& Wang, 2013), while crushed oyster shells can be used as a calcium carbonate source for poultry (Morris, Backeljau, \& Chapelle, 2019). In addition, oysters are a good source of nutrients for people such as protein, omega-3 fatty acids, vitamins A and E, iodine and selenium (Orban et al., 2002). Further, the high content of zinc, vitamin $B$ and $C$ in the oyster can help treat male infertility (Ogunlesi, Okiei, Ofor, \& Awonuga, 2009).

\section{Marine Spatial Planning}

MSP is an integrated ecosystem-based management system employed to organise the usage of marine space and create balance between the demands for socioeconomic development and the needs for environmental sustainability. MSP is also known as maritime spatial planning. According to Ehler and Douvere (2009), MSP involves a public process of analysing and allocating spatial and temporal distributions of human activities in marine areas to achieve ecological, economic and social objectives, which are usually achieved through the political process. It is also defined as a practical way to manage uses of marine space by balancing the 
interaction of human influence such as shipping and mining with the needs of the marine environment (Santos, Ehler, Agardy, Andrade, \& Orbach, 2019).

Ongoing anthropogenic activities are a tragedy for the environment, and there are no ocean areas in this world that are not affected by human activities (Santos et al., 2019). Therefore, the environments need to be managed sustainably and properly so that ecosystems can continue to function well. MSP is a futureoriented tool of marine management that aims to protect ecosystems by reducing conflicting uses and providing guidelines regarding which activities may occur in particular areas (Crowder et al., 2006). The essential aspect of MSP is employing an ecosystem-based approach to manage selected ocean areas to create long-term sustainability in the utilisation of marine resources (Aziz et al., 2019).

When implemented properly, MSP can deliver numerous and various benefits. Among the benefits are reduction in conflicts between ocean space users and nature, reduction in the cumulative effects of human activities on particular marine ecosystems, promotion of the efficient use of space and resources, identification and improved protection for cultural heritage, and increased opportunities for local communities to participate in the management of coastal areas utilised by them (Ehler \& Douvere, 2009). MSP is in line with Agenda 21 of UNCED (Rio de Janeiro), which aims to involve local communities with authorities in safeguarding the environment to tackle issues on pollution and protection of natural resources. Hence, MSP promotes the concept of sustainable development by encouraging consideration of the impacts of any actions on the local economy, local environment and local community, and seeking solutions to achieve balance between them.

The concept of sustainable management of coastal states was mentioned in several international conferences many years ago. Examples are Article 192 of the United Nations Convention on the Law of the Sea 1982 (chapter 17) and Agenda 21 of the UNCED in 1992, which urge the development of sustainable management to protect the marine environment. In addition, the Convention on Biological Diversity stresses the need for the involvement of different stakeholders to ensure achievement in management, aiming for the conservation of ecosystems. Bartel and Janssen (2016) and Domínguez-tejo, Metternicht, Johnston, and Hedge (2016) reported that the application of MSP is important for the sustainable planning of marine resources. MSP is a continuing process that requires feedback loops and modification throughout the implementation progress as new information is identified (Ehler \& Douvere, 2009).

MSP is said to have originated during the effort to establish the Great Barrier Reef Marine Park, Australia, in 1975 (Ehler, Zaucha, \& Gee, 2018). As mentioned by Dunstan et al. (2016), MSP was implemented as part of this effort as 
well as for the Australian Coral Sea Marine Reserve. However, the MSP for the Great Barrier Reef Marine Park is among the best of MSP examples, and it initiated implementation across the world. In the United States, the MSP concept is known as coastal and marine spatial planning, which has been adopted based on science to analyse current ocean space uses to develop a new coastal management approach (George, Sabaruddin, \& Chong, 2016). Norway has adopted MSP in three of their exclusive economic zones, which cover over 2 million $\mathrm{km}^{2}$, to conserve their ocean due to commercial shipping activities, oil and gas industry and exhaustive fishery activities (Santos et al., 2019).

In Canada, MSP has replaced the integrated management plan in Canada, which was used from 2008, and it has already been implemented in Beaufort Sean and the Pacific North Coast (George et al., 2016). In the Netherlands, MSP was first completed in 2005 to protect the coastal areas because of the presence of offshore wind farms, while Germany implemented its first MSP in 2003 by introducing closed areas during fish spawning seasons and sequential rotation for exploited areas (Santos et al., 2019). In China, MSP approaches commonly used were known as marine functional zoning, a policy created by the State Oceanic Administration. The Chinese Government then proposed a new round of MSP known as marine ecological redline (MERL) zones to create balance between development, the economy and the environment (Lu et al., 2015; Hu et al., 2019).

MSP is a new concept in Malaysia. As reported by the World Wildlife Fund (WWF) in 2015, Sabah was the first state in Malaysia to launch MSP in June 2015 to protect the Semporna Priority Conservation Area. The state government initiated MSP to conserve the affected areas: tourism hot spots famous for diving, snorkelling and various activities, especially Pulau Mabul, Pulau Kapalai and Pulau Sipadan (Yatim, Omar, Abdullah, \& Sarip, 2018). The project was organised by the Town and Regional Planning Department Sabah in cooperation with WWF Malaysia. In 2016, the Sabah MSP was recognised internationally when it was awarded an International Award for Planning Excellence from the Royal Town Planning Institute in the United Kingdom.

In addition, MSP implementation in central Terengganu has been proposed to protect three marine parks, those being Pulau Redang, Pulau Lang Tengah and Pulau Kapas, which are extremely popular ecotourism destinations in Terengganu (Aziz et al., 2019). With the advantages of MSP to reduce conflict in the marine environment and achieve economic and ecological sustainability (Vaughan \& Agardy, 2020), its implementation is crucial for sustainable wetland management. This is because wetlands have been encountering numerous tensions between social, economic and environmental goals in land resources management over the last decades, which have hindered constructive decision- 
making, resulting in a rapid depletion of their environmental value (Chuang et al., 2018).

\section{Methodology}

Data in this study were generated from the quantitative approach, which was employed to analyse the data collected using the survey method. The survey aimed to examine local community awareness and the importance of oysters in local socio-economic activities. The survey was divided into four sections. Section One explored the demographic profile of respondents, such as gender, age, race, marital status and occupation. Section Two related to awareness of the importance of habitat sustainability in marine ecology. Section Three emphasised the roles of the oyster and its habitat in the Setiu Wetland ecosystems. Questions in Section Four focused on awareness of the importance of oysters to the socio-economics of the local communities.

The survey was conducted with relevant local stakeholders (Chang \& Lin, 2016; Hoshino, van Putten, Girsang, Resosudarmo, \& Yamazaki, 2017), in this case the local community of three villages in Setiu Wetland. The survey was conducted in Kampung Gong Batu, Kampung Pengkalan Gelap and Kampung Fikri on 35 September 2019. A total of 185 respondents from these three villages were interviewed. These three kampongs were selected based on their locations near to the oyster habitats in Setiu Wetland. The data were descriptively analysed based on frequency and percentage to study awareness among local communities of the ecological and economic importance of oysters.

A site visit was conducted, and a few separate meetings were held with the chairmen of the Village Community Management Council to identify the potential respondents among the villagers. A pilot survey was carried out on 14 July 2019 prior to the survey in September 2019.

\section{Findings and Discussions}

The table below shows the demographic profiles of the 185 respondents.

Table 2: Demographic profiles of respondents

\begin{tabular}{lcc}
\hline \multicolumn{1}{c}{ Categories } & $\begin{array}{c}\text { Frequency } \\
(\mathbf{N}=\mathbf{1 8 5})\end{array}$ & $\begin{array}{c}\text { Percentage } \\
\mathbf{( \% )}\end{array}$ \\
\hline 1. Gender & & \\
Male & 111 & 60.00 \\
Female & 74 & 40.00 \\
\hline
\end{tabular}




\begin{tabular}{|c|c|c|}
\hline \multicolumn{3}{|l|}{ 2. Age } \\
\hline$<18$ & 1 & 0.54 \\
\hline $18-24$ & 22 & 11.89 \\
\hline $25-34$ & 23 & 12.43 \\
\hline $35-44$ & 34 & 18.38 \\
\hline $45-54$ & 51 & 27.57 \\
\hline $55-64$ & 37 & 20.00 \\
\hline$<65$ & 17 & 9.19 \\
\hline \multicolumn{3}{|l|}{ 3. Origin } \\
\hline Gong Batu & 77 & 41.62 \\
\hline Pengkalan Gelap & 30 & 16.22 \\
\hline Fikri & 78 & 42.16 \\
\hline \multicolumn{3}{|l|}{ 4. Race } \\
\hline Melay & 184 & 99.46 \\
\hline Chinese & 1 & 0.54 \\
\hline Indian & 0 & 0 \\
\hline Others & 0 & 0 \\
\hline \multicolumn{3}{|l|}{ 5. Marital status } \\
\hline Single & 29 & 15.68 \\
\hline Married & 140 & 75.68 \\
\hline Widowed & 16 & 8.65 \\
\hline Divorced & 0 & 0 \\
\hline \multicolumn{3}{|l|}{ 6. Job status } \\
\hline Fishermen & 43 & 23.24 \\
\hline Farmer & 6 & 3.24 \\
\hline Labours & 7 & 3.78 \\
\hline Others & 129 & 69.73 \\
\hline
\end{tabular}

Source: Fieldwork survey, September 2019

Out of 185 respondents, $60 \%$ were male and $40 \%$ were female. The highest number of respondents was in the age range of $45-54$ years old. Meanwhile only $0.54 \%$ of respondents were below 18 years old. The number of respondents from Kampung Gong Batu, Kampung Fikri and Kampung Pengkalan Gelap were 41.62\%, 42.16\% and $16.22 \%$ respectively. In terms of ethnicity, $99.46 \%$ of respondents were Malay and another $0.54 \%$ was Chinese. The majority of Setiu's population were Malay with a small number of Chinese, Indian and others (Ghazali \& Hamzah, 2014; Mohd. Salim et al., 2015). The majority of the respondents were married (75.68\%). Most respondents were categorised as B40 group (poor group). 


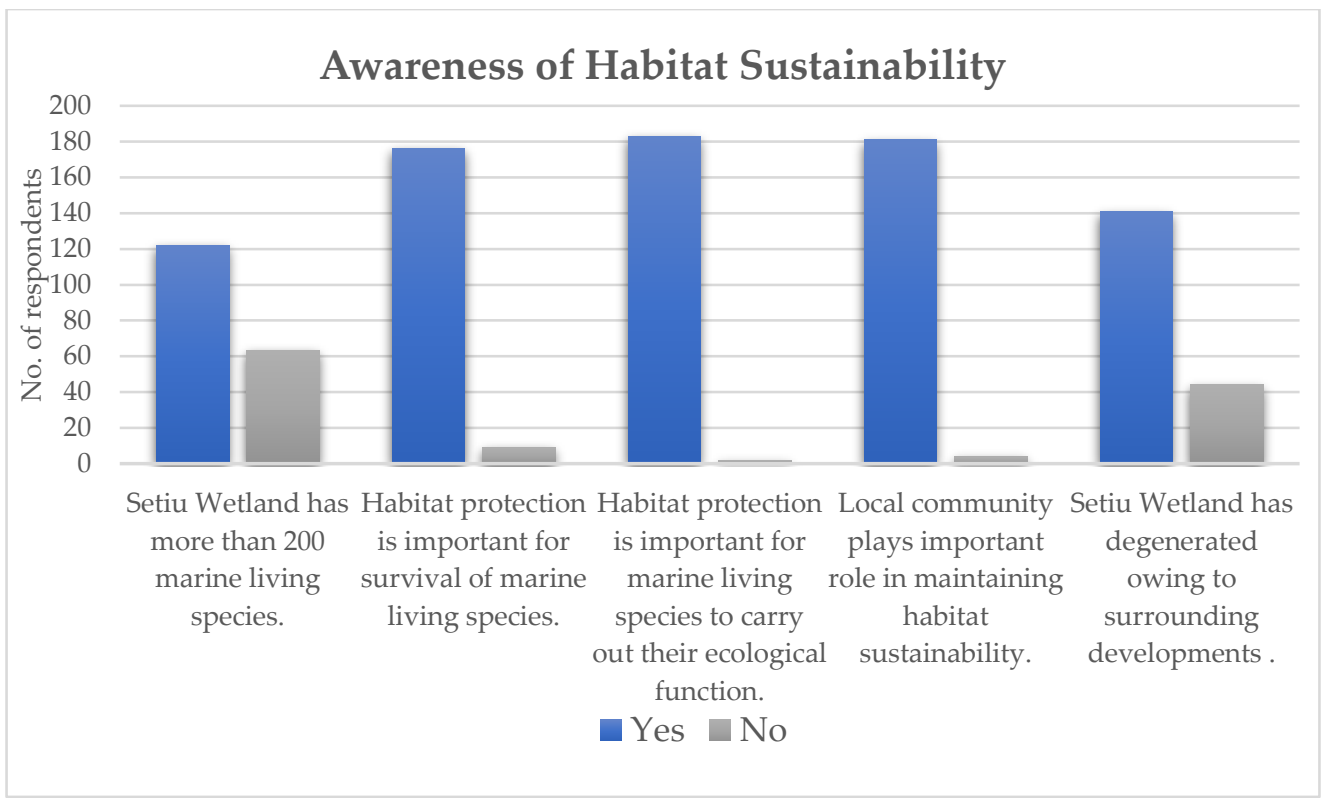

Figure 1: Awareness of habitat sustainability in Setiu Wetland among the local communities

Source: Fieldwork survey, September 2019.

Figure 1 shows that 122 respondents (65.95\%) agreed that Setiu Wetland is home to more than 200 species of living organisms. Meanwhile 63 respondents $(34.05 \%)$ disagreed with the statement. This finding corresponds with the results reported by Haron et al. (2020), who argued that environmental awareness among the local community in Setiu Wetland is of a high level.

Out of 184 respondents, $95.14 \%$ agreed that wetland habitats must be protected for the survival of marine organisms. In addition, $98.92 \%$ also believed that the habitats required protection for other marine species to continue carrying out their ecological functions. They supported the idea of mapping different zones to reduce conflicts between users and to conserve the wetland for the future. Preservation is important to the local community to ensure the wetland continues functioning as nature intended. Ghazali and Hamzah (2014) stated that most of the Setiu Wetland local community relies on natural resources for their incomes. Hence, they are inclined to support any plans or policies that advance the notions of preserving the natural ecosystems of the wetland.

The local community believes (97.84\%) that they play an important role in maintaining the ecosystems' sustainability in the wetland. This finding is in line with a study reported by Badola, Barthwal, and Hussain (2012) on attitudes of local communities towards conservation of mangrove forests in India. The authors 
found that $84 \%$ of locals felt responsible for conservation and $94 \%$ supported an integrated conservation program.

Analysis shows that 141 respondents (76.22\%) agreed that Setiu Wetland ecosystems are degenerating owing to previous and ongoing developments in the wetlands themselves and in surrounding areas. However, 44 respondents $(23.78 \%)$ argued that Setiu Wetland ecosystems have improved as a result of restoration works conducted around the wetland in the past few years. A few major conversation and restoration works in Setiu Wetland have been undertaken since 1995 to date. For example, the conservation programmes for the sea turtle and painted terrapin were established in 1995 (World Wildlife Fund [WWF], 2013). The ecosystems of Setiu Wetland have also been enhanced through a project of planting 1,000 mangroves and nipah saplings along the Setiu River (Scouts, 2009). To empower the local community, the Wetland School of Setiu Project, organised by a locally based NGO, known as the EcoSwed Initiative, aims to promote sustainable community-based ecotourism activities and awareness education programmes (SGP, 2021).

Further, the Setiu Boardwalk in Kampung Pengkalan Gelap has been established and is promoted as an ecotourism activity in Setiu Wetland. With the cooperation of local associations, for example, Sahabat Setiu, since 2005 more than 1,000 trees have been planted each year in the boardwalk areas as part of the Mangrove Replanting Program (Omar, Husin, \& Parlan, 2020). To protect and conserve the ecosystems in Setiu Wetland, Terengganu State Government gazzetted Setiu Wetland as the first state park in Terengganu on 10 May 2018 (Yayasan Diraja Sultan Mizan, 2018). Consequently, the SWSAP was published in December 2019, with goals for sustainable conservation, management and utilisation of the wetland.

Table 3: Awareness of the role of oysters in the ecosystem and changes in size and quantity of oyster in Setiu Wetland

\begin{tabular}{lll}
\hline Question & $\begin{array}{l}\text { Frequency } \\
(\mathrm{N}=185)\end{array}$ & Percentage (\%) \\
\hline $\begin{array}{l}\text { Oysters can be found in Setiu Wetland. } \\
\text { Yes }\end{array}$ & 183 & $\begin{array}{l}98.92 \\
1.08\end{array}$ \\
No & 2 & \\
\hline Oysters play an important role in the & & 82.70 \\
ecosystem. & 153 & 17.30 \\
Yes & 32 & \\
No & & 35.68
\end{tabular}




\begin{tabular}{lll} 
No & 45 & 24.32 \\
Uncertain & 74 & 40.00 \\
\hline The number of oysters is becoming smaller & & \\
Yes & 80 & 43.24 \\
No & 58 & 31.35 \\
Uncertain & 47 & 25.41 \\
\hline Number of people usually noticed collecting & & \\
oyster at one time. & & \\
0 & 46 & 24.86 \\
$1-5$ & 60 & 32.43 \\
$6-10$ & 43 & 23.24 \\
$11-15$ & 19 & 10.27 \\
$16-20$ & 2 & 1.08 \\
$21-25$ & 3 & 1.62 \\
$>25$ & 12 & 6.49 \\
\hline
\end{tabular}

Source: Fieldwork survey, September 2019.

The majority of respondents $(98.92 \%)$ knew that Setiu Wetland has an oyster population. They also knew $(82.70 \%)$ that oysters are important to the Setiu Wetland ecosystems. However, the majority of the respondents (40\%) could not verify whether there have been changes in the oyster size. Meanwhile, 35.68\% argued that the oyster size is becoming smaller and $24.32 \%$ disagreed with the statement.

Out of 184 respondents, $43.24 \%$ agreed, $31.35 \%$ disagreed and $25.41 \%$ were uncertain when asked about the decline in the oyster population in Setiu Wetland. This result is similar to results from a study conducted by Gillies et al. (2020) on the status of oyster reefs ecosystem in southern and eastern Australia. The authors found a decline in the reef's extent and a reduction in the oyster biomass. A few reasons may be attributed to the decline in oyster populations, for example, the bottom dredging fishing method, habitat loss, over-harvesting and water quality degradations (Kirby, 2004). In the case of Setiu Wetland, habitat loss and water quality deterioration would threaten oysters and cause a reduction in oyster biomass. 


\section{SOCIO-ECONOMIC IMPORTANCE OF \\ OYSTERS AMONG LOCAL \\ COMMUNITIES}

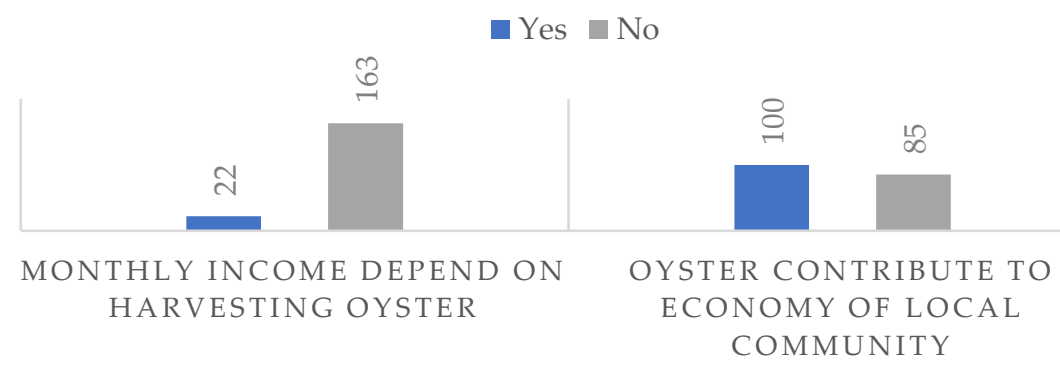

Figure 2: Economic contributions of oysters among local communities in Setiu Wetland

\section{Source: Fieldwork survey, September 2019.}

Figure 2 shows that 163 respondents $(88.11 \%)$ did not depend on oysters for their household incomes. Only 22 respondents $(11.89 \%)$ depended on oysters to generate extra income. Of all respondents, $54.05 \%$ knew about the oyster contribution to local socio-economic activities. Meanwhile, $45.95 \%$ did not know about oysters' contribution to local socio-economic activities. This result is similar to Ozbay and Smith (2018), who argued that oyster productivity is used as a solution to finance the local community.

Table 4: Total sales gained from oyster harvesting by total trips per month

\begin{tabular}{|c|c|c|c|c|}
\hline $\begin{array}{l}\text { Number of } \\
\text { trips in one } \\
\text { month }\end{array}$ & $\begin{array}{l}\text { Monthly income } \\
\text { from oyster sales }\end{array}$ & $\begin{array}{l}\text { Annual income } \\
\text { from oyster } \\
\text { sales (monthly } \\
\text { income x } 12 \\
\text { months) } \\
\end{array}$ & $\begin{array}{l}\text { Number of } \\
\text { respondents }\end{array}$ & $\begin{array}{l}\text { \% of respondents } \\
(\mathrm{No} . \text { of } \\
\text { respondents } / \mathrm{N}) \text {, } \\
\mathrm{N}=19\end{array}$ \\
\hline \multirow{4}{*}{1} & RM30 & RM360 & 2 & $0.10 \%$ \\
\hline & RM35.5 & RM426 & 3 & $0.16 \%$ \\
\hline & RM45.5 & RM546 & 3 & $0.16 \%$ \\
\hline & RM50 & RM600 & 11 & $0.58 \%$ \\
\hline \multirow{4}{*}{5} & RM150 & RM1800 & 2 & $0.10 \%$ \\
\hline & RM177.50 & RM2130 & 3 & $0.16 \%$ \\
\hline & RM227.50 & RM2730 & 3 & $0.16 \%$ \\
\hline & RM250 & RM3000 & 11 & $0.58 \%$ \\
\hline
\end{tabular}

Source: Fieldwork survey, September 2019. 
All respondents stated that they harvested oysters between one and five times for their supplementary incomes monthly. This result is supported by a study conducted by Syerrina, Naeim, Safiih, and Nuredayu (2017) on factors related to incomes among the coastal community in Setiu Wetland. The authors argued that the local artisanal fishermen were not able to earn a sufficient basic income by solely focusing on fishing. Therefore, they tended to take on part-time jobs to generate extra income.

Table 4 provides the incomes of 19 respondents involved in harvesting oysters. Of the respondents, $0.10 \%$ gained extra income from harvesting oysters of between RM30 and RM150 monthly or RM360 and RM1800 annually. Meanwhile, $0.16 \%$ gained between RM35.50 and RM177.50 monthly or RM426 and RM2130 annually; $0.16 \%$ gained between RM45.50 and RM227.50 monthly or RM546 and RM2730 annually; and, finally, 0.58\% gained between RM50 and RM250 monthly or RM600 and RM3000 annually.

\section{Conclusion and Recommendations}

Setiu Wetland is gazetted as the Terengganu State Park. Following the gazetting, the SWSAP was implemented. The SWSAP indicates that the local authority is the agency responsible for implementing the special area plan. In addition, the Terengganu State Park Committee acts as the competent authority to embed the MSP element in the implementation of the SWSAP, which the State Park aims for sustainable conservation, management and utilisation of the wetland. The SWSAP, which was launched under the latest amendment of the Town and Country Planning Act 1976 (Act 172), section 16B (1)(2)(3), is the enabling law to implement MSP as it provides a detailed guide for planning and development control of a particular area and is tool for proper development of Setiu Wetland with standard procedures.

This study highlights that local community members were aware of the importance of oysters to the Setiu Wetland. They also agreed that the oyster habitats must be protected to maximise their ecological roles in Setiu Wetland habitats and ecosystems. The local community's awareness is vital to introduce and smooth implementation of MSP in the future. This finding is significant as a baseline for introducing MSP as a potential mechanism for governing wetlands in Malaysia. It will help promote MSP in Malaysia as an ecosystem-based approach to manage coastal resources. 


\section{Acknowledgment}

This paper acknowledges the funding from the Ministry of Higher Education HICoE Research Grant under Vot 66928.

\section{References}

Abelshausen, B., Vanwing, T., \& Jacquet, W. (2015). Participatory integrated coastal zone management in Vietnam: Theory versus practice case study: Thua Thien Hue province. Journal of Marine and Island Cultures, 4(1), 42-53. https://doi.org/10.1016/j.imic.2015.06.004

Affizah, N., Vedamanikam, V. J., \& Shazilli, N. A. M. (2009). Concentration of arsenic and mercury in the oyster (Crassostrea iredalei) from Setiu lagoon, Terengganu. Toxicological and Environmental Chemistry, 91(2), 259-265. https://doi.org/10.1080/02772240802166573

Akdeniz, D. (2017). Oyster symbolism in the art of painting. Journal of Social and Humanities Sciences Research, 4, 339-354. https://doi.org/10.1177/0265407585022005An. N. T., Phung, N. K., \& Chau, T. B. (2008). Integrated Coastal Zone Management in Vietnam: Pattern and Perspectives. Journal of Water Resources and Environmnetal Engineering, 23 (23), 297-304.

Aziz, N., Muhammad, Z., Farahdilah, G., Talaat, W. I. A. W., \& Saputra, J. (2019). Marine Spatial Planning: The way forward for sustainable development of Central Terengganu, Malaysia. Journal of Southwest Jiaotong University, 54(4), 1-11. https://doi.org/10.35741/issn.0258-2724.54.4.9

Azlisham, M., Vedamanikam, V. J., \& Shazilli, N. A. M. (2009). Concentrations of cadmium, manganese, copper, zinc, and lead in the tissues of the oyster (Crassostrea iredalei) obtained from Setiu Lagoon, Terengganu, Malaysia. Toxicological and Environmental Chemistry, 91(2), 251-258. https://doi.org/10.1080/02772240802138127

Badola, R., Barthwal, S., \& Hussain, S. A. (2012). Attitudes of local communities towards conservation of mangrove forests: A case study from the east coast of India. Estuarine, Coastal and Shelf Science, 96, 188-196. https://doi.org/10.1016/j.ecss.2011.11.016

Bai, J., Cui, B., Cao, H., Li, A., \& Zhang, B. (2013). Wetland degradation and ecological restoration. The Scientific World Journal, 2013, 1-2. https://doi.org/10.1155/2013/523632

Bakar, N. H. A., Jusoh, A., Ahmad, M. F., Noor, M. J. M. M., \& Norzilah, A. (2016). A spatial nutrient distribution due to seabass aquaculture activities at Setiu, Terengganu, Malaysia. Journal of Fisheries and Aquatic Science, 11(5), 332348. https://doi.org/10.3923/jfas.2016.332.348 
Barnette, P., \& Wiwekwin, N. (2018). Integrated coastal management implementation and scaling up in Chonburi Province, Thailand. In C. Thia-Eng, C. L. Ming, G. Jacinto, S. A. Ross, \& D. Bonga (Eds.), Local contributions to global sustainable agenda: Case studies in integrated coastal management in the East Asian seas region (pp. 469-482). Quezon City: Partnerships in Environmental Management for the Seas of East Asia (PEMSEA) and Coastal Management Center (CMC).

Bartel, S., \& Janssen, G. (2016). Underground spatial planning - Perspectives and current research in Germany. Tunnelling And Underground Space Technology, 55, 112-117. https://doi.org/10.1016/j.tust.2015.11.023

Beeharry, Y., Makoondlall-Chadee, T., \& Bokhoree, C. (2014). Policy analysis for performance assessment of integrated coastal zone management initiatives for coastal sustainability. APCBEE Procedia, 9, 30-35. https://doi.org/10.1016/j.apcbee.2014.01.006

Brander, L. M., Wagtendonk, A. J., Hussain, S. S., McVittie, A., Verburg, P. H., de Groot, R. S., \& van der Ploeg, S. (2012). Ecosystem service values for mangroves in Southeast Asia: A meta-analysis and value transfer application. Ecosystem services, 1(1), 62-69.

Chang, Y., \& Lin, B. (2016). Improving marine spatial planning by using an incremental amendment strategy: The case of Anping, Taiwan. Marine Policy, 68, 30-38. https://doi.org/10.1016/j.marpol.2016.02.004

Chuang, Y. H., Yu, R. F., Chen, W. Y., Chen, H. W., \& Su, Y. T. (2018). Sustainable planning for a coastal wetland system with an integrated ANP and DPSIR model for conflict resolution. Wetlands Ecology and Management, 26(6), 1015-1036.

Coen, L. D., Brumbaugh, R. D., Bushek, D., Grizzle, R., Luckenbach, M. W., Posey, M. H., Tolley, S. G. (2007). Ecosystem services related to oyster restoration. Marine Ecology Progress Series, 341, 303-307.

Crowder, L. B., Osherenko, G., Young, O. R., Airamé, S., Norse, E. A., Baron, N., Wilson, J. A. (2006, August). Resolving mismatches in U.S. ocean governance. SCIENCE, 313, 617-618. https://doi.org/10.1109/DSN.2017.15

Cruickshank, E. W., Schneeberger, K., \& Smith, N. (Eds.). (2012). A pocket guide to sustainable development governance. n.p.: Commonwealth Secretariat. Retrieved from https://www.circleofblue.org/wpcontent/uploads/2012/07/PocketGuidetoSDGEdition2webfinal\%E2\%80\%9 3Stakeholder-Forum.pdf

Davidson, N. C., Fluet-Chouinard, E., \& Finlayson, C. M. (2018). Global extent and distribution of wetlands: Trends and issues. Marine and Freshwater Research, 69(4), 620-627. https://doi.org/10.1071/MF17019 
Dernbach, J. C. (2003). Achieving sustainable development: The centrality and multiple facets of integrated decisionmaking. Indiana Journal of Global Legal Studies, 10(1), 247-285.

Domínguez-tejo, E., Metternicht, G., Johnston, E., \& Hedge, L. (2016). Marine spatial planning advancing the ecosystem-based approach to coastal zone management: A review. Marine Policy, 72, 115-130. https://doi.org/10.1016/j.marpol.2016.06.023

Douvere, F. (2008). The importance of marine spatial planning in advancing ecosystem-based sea use management. Marine Policy, 32, 762-771. https://doi.org/10.1016/j.marpol.2008.03.021

Dunstan, P. K., Bax, N. J., Dambacher, J. M., Hayes, K. R., Hedge, P. T., Smith, D. C., \& Smith, A. D. M. (2016). Using ecologically or biologically significant marine areas (EBSAs) to implement marine spatial planning. Ocean and Coastal Management, 121, 116-127. https://doi.org/10.1016/j.ocecoaman.2015.11.021

Dyke, F. V., \& Lamb, R. F. (2020). Conservation biology: Foundations, concepts, applications. Cham: Springer.

Ehler, C. N., \& Douvere, F. (2009). A step-by-step approach towards ecosystem-based management. Paris: UNESCO.

Ehler, C., Zaucha, J., \& Gee, K. (2018). Maritime/marine spatial planning at the interface of research and practice. In J. Zaucha \& K. Gee (Eds.), Marine spatial planning (pp. 1-22). Cham: Palgrave Macmillan.

French McCay, D. P., Peterson, C. H., DeAlteris, J. T., \& Catena, J. (2003). Restoration that targets function as opposed to structure: Replacing lost bivalve production and filtration. Marine Ecology Progress Series, 264, 197212. https://doi.org/10.3354/meps264197

George, M., Sabaruddin, J. S. H., \& Chong, V. C. (2016). Marine spatial planning: What does it have to offer Malaysia? International Journal of Marine and Coastal Law, 31(2), 242-278. https://doi.org/10.1163/15718085-12341397

Gerhartz-Abraham, A., Fanning, L. M., \& Angulo-Valdes, J. (2016). ICZM in Cuba: Challenges and opportunities in a changing economic context. Marine Policy, 73, 69-76. https://doi.org/10.1016/j.marpol.2016.07.009

Ghazali, N., \& Hamzah, A. (2014, May 9-11). Preserving the uniqueness cultural landscape in Setiu Wetlands. Paper presented at the International Conference on Urban and Regional Planning (ICURP) 2014, Skudai, Johor, Malaysia.

Gillies, C. L., Castine, S. A., Alleway, H. K., Crawford, C., Fitzsimons, J. A., Hancock, B., \& zu Ermgassen, P. S. E. (2020). Conservation status of the oyster reef ecosystem of southern and eastern Australia. Global Ecology and 
Conservation, 22, 1-16. https://doi.org/10.1016/j.gecco.2020.e00988

Govan, H., Tawake, A., \& Tabunakawai, K. (2006). Community-based marine resource management in the South Pacific. Parks, 16(1), 63-67.

Hadi, S. P. (2018). Integrated community based coastal management: Lesson from the field. IOP Conference Series: Earth and Environmental Science, 116(1), 1-4. https://doi.org/10.1088/1755-1315/116/1/012064

Hagan, A. M. O., \& Ballinger, R. C. (2010). Implementing integrated coastal zone management in a national policy vacuum: Local case studies from Ireland. Ocean and Coastal Management, 53(12), 750-759. https://doi.org/10.1016/j.ocecoaman.2010.10.014

Haron, N. F., Aziz, I., Ghani, H. A., \& Amirah, N. A. (2020). Environmental awareness: Do people really concern about the Setiu Wetlands in Terengganu, Malaysia? International Journal of Academic Research in Business and Social Sciences, 10(10), 1066-1079. https://doi.org/10.6007/IJARBSS/v10i10/8268

Hoshino, E., van Putten, E. I., Girsang, W., Resosudarmo, B. P., \& Yamazaki, S. (2017). Fishers' perceived objectives of community-based coastal resource management in the Kei islands, Indonesia. Frontiers in Marine Science, 4, 111. https://doi.org/10.3389/fmars.2017.00141

Hu, W., Yu, W., Ma, Z., Ye, G., Dang, E., \& Huang, H. (2019). Assessing the ecological sensitivity of coastal marine ecosystems: A case study in Xiamen Bay, China. Sustainability, 11(22), 6372.

Ibrahim, I., Aziz, N. A., \& Hanifah, N. A. (2012a). The laws of wetness: the legislative framework in Malaysia regarding wetlands conservation. Procedia-Social and Behavioral Sciences, 50, 574-581.

Ibrahim, I., Aminudin, N., Young, M. A., \& Yahya, S. A. I. (2012b). Education for wetlands: Public perception in Malaysia. Procedia-Social and Behavioral Sciences, 42, 159-165.

Ikhwanuddin, M., Azmi, W. A., Borkhanuddin, M. H., Muhammad, S. R. S., \& Idris, I. (2017). Improving the health of setiu wetlands ecosystems and productivity of crustacean resources for livelihood enhancement. Journal of Sustainability Science and Management, 3, 1-7.

Jacobides, M. G., Cennamo, C., \& Gawer, A. (2018). Towards a theory of ecosystems. Strategic Management Journal, 39(8), 2255-2276.

Jarvie, M. E. (2016, May 20). Brundtland Report. Encyclopedia Britannica. Retrieved from https://www.britannica.com/topic/Brundtland-Report

Kirby, M. X. (2004). Fishing down the coast: Historical expansion and collapse of oyster fisheries along continental margins. Proceedings of the National Academy of Sciences of the United States of America, 101(35), 13096-13099. 
https://doi.org/10.1073/pnas.0405150101

Liang, C. F., \& Wang, H. Y. (2013). Feasibility of pulverised oyster shell as a cementing material. Advances in Materials Science and Engineering, 2013. https://doi.org/10.1155/2013/809247

Lillis, A., Eggleston, D. B., \& Bohnenstiehl, D. R. (2013). Oyster larvae settle in response to habitat-associated underwater sounds. PLoS ONE, 8(10), 21-23. https://doi.org/10.1371/journal.pone.0079337

Mensah, J. (2019). Sustainable development: Meaning, history, principles, pillars, and implications for human action: Literature review. Cogent Social Sciences, $5(1), 1-21$.

Mohd. Salim, Mohamad., F., \& Shahrudin, R. (2015). Setiu: More than a wetland. In F. Mohamad, J. Mohd. Salim, J. Mohd. Jani, \& R. Shahrudin (Eds.), Setiu Wetlands: Species, ecosystem and livelihoods (1st ed.). Kuala Terengganu: Penerbit Universiti Malaysia Terengganu.

Moomaw, W. R., Chmura, G. L., Davies, G. T., Finlayson, C. M., Middleton, B. A., Natali, S. M., ... \& Sutton-Grier, A. E. (2018). Wetlands in a changing climate: science, policy and management. Wetlands, 38(2), 183-205.

Morris, J. P., Backeljau, T., \& Chapelle, G. (2019). Shells from aquaculture: a valuable biomaterial, not a nuisance waste product. Reviews in Aquaculture, 11(1), 42-57. https://doi.org/10.1111/raq.12225

Najiah, M., Nadirah, M., Lee, K. L., Lee, S. W., Wendy, W., Ruhil, H. H., \& Nurul, F. A. (2008). Bacteria flora and heavy metals in cultivated oysters Crassostrea iredalei of Setiu Wetland, East Coast Peninsular Malaysia. Veterinary Research Communications, 32(5), 377-381. https://doi.org/10.1007/s11259-008-9045-y

Newell, R. I. E., \& Koch, E. W. (2004). Modeling seagrass density and distribution in response to changes in turbidity stemming from bivalve filtration and seagrass sediment stabilisation. Estuaries, 27(5), 793-806. https://doi.org/10.1007/BF02912041

Ogunlesi, M., Okiei, W., Ofor, E., \& Awonuga, O. (2009). Determination of the concentrations of zinc and vitamin $\mathrm{C}$ in oysters and some medicinal plants used to correct male factor infertility. Journal of Natural Products, 2, 89-97.

Omar, H., Husin, T. M., \& Parlan, I. (Eds.). (2020). Status of mangroves in Malaysia. Kepong: Forest Research Institute Malaysia, Ministry of Energy and Natural Resources. Retrieved from https://www.researchgate.net/profile/Hamdan-Omar3/publication/344608859_STATUS_OF_MANGROVES_IN_MALAYSIA/li nks/5fd385c292851c13fe7ac0ad/STATUS-OF-MANGROVES-INMALAYSIA.pdf 
Orban, E., Lena, G. Di, Nevigato, T., Casini, I., Marzetti, A., \& Caproni, R. (2002). Seasonal changes in meat content, condition index and chemical composition of mussels (Mytilus galloprovincialis) cultured in two different Italian sites. European Food Research E Technology., 226(6), 57-65. https://doi.org/10.1007/978-1-4613-1113-3_7

Ozbay, G., \& Smith, S. L. (2018). Are aquaculture practices sustaining our goal to restore oysters (Crassostrea virginica)? In G. Diarte-Plata \& R. EscamillaMontes (Eds.), Aquaculture - plants and invertebrates. London: IntechOpen. Retrieved from http://www.intechopen.com/books/trends-intelecommunications-technologies/gps-total-electron-content-tecprediction-at-ionosphere-layer-over-the-equatorialregion\%0AInTec\%0Ahttp://www.asociatiamhc.ro/wpcontent/uploads/2013/11/Guide-to-Hydropower.pdf

Padfield, R., Waldron, S., Drew, S., Papargyropoulou, E., Kumaran, S., Page, S., ... \& Tham, M. H. (2015). Research agendas for the sustainable management of tropical peatland in Malaysia. Environmental Conservation, 42(1), 73-83.

Panawala, L. (2017). Difference between Scavenger and Decomposer. Retrieved from

https://www.researchgate.net/publication/320413590_Difference_Betwee n_Scavenger_and_Decomposer

Parvin, G. A., Ahsan, S. M. R., \& Shaw, R. (2010, January). Community-based coastal zone management in Bangladesh. Community and Coasatal Zone Management, 165-184.

Poh, S. C., Ng, N. C. W., Suratman, S., Mathew, D., \& Tahir, N. M. (2019). Nutrient availability in the setiu wetland lagoon, Malaysia: Trends, possible causes and environmental impacts. Environmental Monitoring and Assessment, 191(3), 1-13. https://doi.org/10.1007/s10661-018-7128-y

Portman, M. E., Esteves, L. S., Le, X. Q., \& Khan, A. Z. (2012). Improving integration for integrated coastal zone management: An eight country study. Science of the Total Environment, 439, 194-201.

Rodney, W. S., \& Paynter, K. T. (2006). Comparisons of macrofaunal assemblages on restored and non-restored oyster reefs in mesohaline regions of Chesapeake Bay in Maryland. Journal of Experimental Marine Biology and Ecology, 335, 39-51. https://doi.org/10.1016/j.jembe.2006.02.017

Saleh, K. M., \& Muslim, A. @ M. S. M. (2017). Monitoring land-use and land-cover change in Setiu Wetland, Terengganu, Malaysia using remote sensing and GIS. International Proceedings of Chemical, Biological and Environmental Engineering, 102, 10-16. https://doi.org/10.7763/IPCBEE.

Santos, C. F., Ehler, C. N., Agardy, T., Andrade, F., \& Orbach, M. K. (2019). Marine 
spatial planning. In C. Sheppard (Ed.), World seas: An environmental evaluation, Volume III: Ecological issues and environmental impacts (2nd ed.) (pp. 571-592). London: Elsevier Ltd. https://doi.org/10.1016/B978-0-12805052-1.00033-4

Scouts. (2009). Project orion plants 1,000 mangroves in Malaysia. Retrieved from https://www.scout.org/id/node/6249

Selig, E. R., Mckinnon, M. C., Turner, W. R., Hole, D. G., Chu, J., Allison, E. H., Holland, M. B. (2019). Mapping global human dependence on marine ecosystems. Conservation Letter, 1-10. https://doi.org/10.1111/conl.12617

SGP. (2021). The GEF Small Grants Programme. Wetland School of SetiuCommunity Based Wetland Education and Awareness Center. Retrieved from https://sgp.undp.org/spacial-itemid-projects-landing-page/spacialitemid-project-search-results/spacial-itemid-projectdetailpage.html?view=projectdetail\&id=29702

Shaharuddin, S., Chan, N. W., Zakaria, N. A., Ab. Ghani, A., Chang, C. K., \& Roy, R. (2014). Constructed wetlands as a natural resource for water quality improvement in Malaysia. Natural Resources, 5(7), 292-298.

Suratman, S., Hussein, A. N. A. R., Tahir, N. M., Latif, M. T., Mostapa, R., \& Weston, K. (2016). Seasonal and spatial variability of selected surface in Setiu wetland, Terengganu, Malaysia. Sains Malaysiana, 45(4), 551-558.

Syerrina, Z., Naeim, A. R., Safiih, L. M., \& Nuredayu, Z. (2017). Explorative spatial analysis of coastal community incomes in Setiu Wetlands: Geographically weighted regression. International Journal of Applied Engineering Research, 12(18), 7392-7396.

Teh, C. P., Zulfigar, Y., \& Tan, S. H. (2012). Epinephrine and 1-DOPA promote larval settlement and metamorphosis of the tropical oyster, Crassostrea iredalei (Faustino, 1932): An oyster hatchery perspective. Aquaculture, 338341, 260-263. https://doi.org/10.1016/j.aquaculture.2012.01.014

Tsujimoto, M., Kajikawa, Y., Tomito, J., \& Matsumoto, Y. (2018). A review of the ecosystem concept - towards coherent ecosystems design. Technological Forecasting \& Social Change, 136, 49-58.

Vaughan, D., \& Agardy, T. (2020). Marine protected areas and marine spatial planning-allocation of resource use and environmental protection. In J. Humphreys \& R. W. E. Clark (Eds.), Marine protected areas: Science, policy and management (pp. 13-35). n.p.: Elsevier.

Viñuales, J. E. (Ed.). (2015). The Rio declaration on environment and development: A commentary. Oxford: Oxford University Press.

World Bank. (2009). World Development Indicators. Keeping the essentials flowing: promoting food security and sustainable livelihood through integrated coastal management.

Retrieved

from 
https://documents1.worldbank.org/curated/en/584581502867051841/pdf/1133

86-WP-Casestudy-v1n1-batangas-PUBLIC.pdf.

Wan Mohd., W. R. (2013). Guest editorial: Pledge for the environment-25 years later. Journal of Tropical Forest Science, 25(3), 273-277.

World Wildlife Fund (WWF). (2013). First turtle and terrapin mini gallery in Setiu to serve as information centre and ecotourism attraction. Retrieved from https://www.wwf.org.my/?15440/First

Yahya, N., Bachok, Z., Zakaria, N. Z., Mohd. Taufeq, Z., Rosli, N. S., \& Bachok, Z. (2016). Ecology of bivalves in the lagoon area of Setiu. Middle East Journal of Scientific Research, 24(6), 2145-2151. https://doi.org/10.5829/idosi.mejsr.2016.24.06.23657

Yatim, M. H. M., Omar, A. H., Abdullah, N. M., \& Sarip, A. (2018). Extending the concept of institutional analysis to the marine spatial planning practice. IOP Conference Series: Earth and Environmental Science, 169(1). https://doi.org/10.1088/1755-1315/169/1/012010

Yayasan Diraja Sultan Mizan. (2018). Memorandum Yayasan Diraja Sultan Mizan mengenai pembangunan Tanah Bencah Setiu sebagai taman negeri dan warisan dunia. Retrieved from http://ydsm.my/?p=9503

Zedler, J. B. (2004). Compensating for wetland losses in the United States. Ibis, 146(Suppl. 1), 92-100. https://doi.org/10.1111/j.1474-919X.2004.00333.x

Cite this paper (APA):

W. Y. Lua, N. Aziz, F. Ghazali, I. Idris, N. H. A. Rasid \& W. I. A. W. Talaat. (2021). Marine Spatial Planning and the Local Community's Awareness of Ecosystems in Setiu Wetland. JATI-Journal of Southeast Asian Studies, 26(1), 97-123 